\title{
Development of decision support system for e-supplier selection in Indian mechanical manufacturing industry using distance based approximation
}

\author{
Alok Kumar ${ }^{a^{*}}$, Ramesh Kumar Garg ${ }^{\mathrm{b}}$ and Dixit Garg
}

${ }^{a}$ Research Scholar, Mechanical Engineering Department, National Institute of Technology, Kurukshetra, India

${ }^{b}$ Professor and Chairman, Mechanical Engineering Department Deenbandhu Chhotu Ram University of Science \& Technology, Murthal, Sonepat, India

cProfessor, Mechanical Engineering Department, National Institute of Technology, Kurukshetra

\begin{tabular}{l}
\hline C H R O N I C L E \\
\hline Article history: \\
Received October 19, 2018 \\
Received in revised format: \\
October 28, 2018 \\
Accepted December 6, 2018 \\
Available online \\
December 6, 2018 \\
\hline Keywords: \\
e-supplier \\
Supplier selection \\
e-supply chain \\
Distance based approximation \\
(DBA) \\
Manufacturing sector \\
Indian industries
\end{tabular}

\begin{abstract}
A B S T R A C T
This paper proposes a framework to develop a deterministic model for the valuation, selection and grading (ranking) of e-suppliers by using Modified Distance Based Approach (MDBA), which has not been used earlier in e-supplier selection. The e-supplier selection system performs a major part for the successful running of any supply chain. Thus, for effective running of any supply chain, it is necessary to build a system for the selection of e-supplier. Building such a decision support system software is important for the development of any decision support system efficiently with reduced cost, time and effort. The current research is based on 8 criteria and 52 sub-criteria by giving equal weightage to all of them. In this study, the major criteria are disintegrated into small sub-criteria. To validate the results obtained through the proposed distance based approximation method, the results are compared with other methodologies. Finally, with the illustration of the example problem, the applicability of the developed model is described.
\end{abstract}

\section{Introduction}

The development in the utilization of the internet in the manufacturing sector and an increase in production demand has been a major cause of introducing the e-supply chain. e-supplier selection is a new emerging approach which can lead to improvements in delivery lead time, transportation time, effort and cost of any supply chain. Presently, most of the firms recommend e-procurement by introducing automation in managing the business operations (Vaidyanathan \& Devaraj, 2008). In eprocurement various business operations like material handling, quality validation and other value added services are controlled through the internet (Johnson \& Whang, 2002). Quality improvement is the major objective of e-procurement (Kerney, 2005). e-Supplier selection process is a blend of qualitative and quantitative factors which leads to a multi-criteria problem. It requires proper synchronization between these tangible and intangible factors for the selection of the best e-supplier

\footnotetext{
* Corresponding author.

E-mail address: alok.shandilya@yahoo.com (A. Kumar)

(C) 2019 by the authors; licensee Growing Science, Canada. doi: $10.5267 /$ j.dsl.2018.12.001
} 
(Ghodsypour \& Brien, 1998). The main issue involved in e-supplier selection, is the selection of criteria according to the field for the development of a system.

For the improvement in production cycle and supply chain, e-supplier selection has become a necessary variable/factor for the production companies. Various criteria like quality, cost, service, etc. are broadly available for e-supplier selection. These can be further disintegrated into sub-criteria for the ease of decision making and avoiding the ambiguity and vagueness in the decision taken. These criteria and sub-criteria may vary with the difference in the nature of the supply chain. This process of e-supplier selection is very useful for the development of production systems if the criteria finalization and system development successfully take place. During the past few years, production firms faced an era of improvement in terms of advancement in production technology, supply chain system, market globalization and customer demands. World class and domestic competitors are growing day by day, hence, it is necessary for firms to rapidly improve their internal and external processes for staying competitive. In this competitive environment, it is the capability of the firms to strengthen them with minimum cost at a rapid pace than their competitors.

There are varieties supplier selection criteria available in the literature. However, it becomes a challenging process to find out the most suitable and potential criteria among all, which will be more suited to the given problem. The number of criteria for supplier selection also increases day by day with the integration of supply chain in various fields like green supply chain, e-supply chain, etc. This research selects the criteria which are found more suitable for supplier selection and also deals with esupply chain on the basis of quality, cost, service, delivery, etc.

In this study modified distance based approach is used for the selection and grading (ranking) of esupplier for automobile manufacturing firms based on 8 main criteria and 52 sub-criteria. This paper is arranged in 7 sections. Sections 2 introduces about the literature review related to e-supplier ranking criteria and selection methods. Section 3, describes about the existing methodology used for selection. The e-supplier ranking \& selection procedure is described in Section 4. Section 5 presents the model with the help of examples and ranking of e-suppliers. Section 6 refers to the validation of the results with other techniques. Section 7 finally focuses over the result and a conclusion part.

\section{Literature Review}

e- Supplier selection process is the most challenging and necessary task for any supply chain. The study of research provides information about various supplier selection criteria and methodology adopted, are summarized in this section. This section of study is split in two portions (1) e-supplier selection criteria and (2) selection techniques.

\section{1. e- supplier selection criteria}

Supplier selection is a complex procedure in which we work on multi-criteria activities for the selection of a supplier. According to Chang et al. (2007) suppliers are differentiated on the basis of their characteristics like organizational culture, manufacturing procedure, technology capabilities and geographical location for the selection of the best supplier. In the recent study, most of the work in the literature has been found on supply chain management and supplier selection process.

According to Jain et al. (2004) supplier selection process is used in traditional SCM by first setting up the standards for selection criteria and then periodic evaluation is followed to ensure attainment of these standards. Both qualitative and qualitative techniques are used by the researchers discussed in earlier studies for supplier selection (Ramanathan, 2007). Most of the literature found are based on criteria like price, quality, financial status, service, location, delivery, time, and performance (Deng \& Chan, 2011; Aksoy \& Ozturk, 2011; Kara, 2011). These factors, which are explained earlier are very useful for evaluation of supplier (Chang \& Hung, 2010). So, in this literature two types of criteria for esupplier selection are considered. Some criteria belong to traditional supply chain and others are extracted from an e-supply chain as shown in Table 1. 
Table 1

Source of E- Supplier Selection Criteria \& Sub- Criteria

\begin{tabular}{|c|c|c|}
\hline Factor & Indicators & Sources \\
\hline \multirow{5}{*}{ Quality } & Online information Quality & (DeLone \& McLean, 2003), (Fairchild et al., 2004), (Valahzaghard et al., 2011). \\
\hline & Online payment procedure & (Mentzer et al., 2001), (Valahzaghard et al., 2011). \\
\hline & Product Quality & $\begin{array}{l}\text { (Tsai et al., 2010), (Sanayei et al., 2010), (Wu, 2010), (Shemshadi et al., 2011), (Liao \& Kao, 2011), } \\
\text { (Vinodh et al., 2011), (Chang et al., 2011), (Deng \& Chan, 2011), (Aksoy \& Öztürk, 2011), (Kara, } \\
\text { 2011), (Kilincci \& Onal, 2011), (Akarte et al., 2001), (Priya et al., 2012), (Ozkan et al., 2011), } \\
\text { (Ghodsypour \& O'Brien, 1998), (Kar \& Pani, 2014), (Garg et al.), (Pal et al., 2013), (Jain et al., } \\
\text { 2013), (Valahzaghard et al., 2011), (Valahzaghard et al.,2011). }\end{array}$ \\
\hline & Fulfilled Order Accuracy & (Mentzer et al., 2001), (Garg et al., 2010), (Valahzaghard et al., 2011) \\
\hline & Quality Control & $\begin{array}{l}\text { (Ghodsypour \& O’Brien, 1998), (Benyoucef et al., 2003), (Kar \& Pani, 2014), (Jain et al., 2013), } \\
\text { (Jariyal \& Garg 2012). }\end{array}$ \\
\hline \multirow[t]{2}{*}{ Cost } & Product Cost & $\begin{array}{l}\text { (Valahzaghard et al.,2011), (Zhang et al., 2009), (Lee \& Amy, 2009), (Wu et al. 2009), (Sanayei et } \\
\text { al., 2010), (Wu, 2010), (Shemshadi et al., 2011), (Akarte et al., 2001), (Priya et al., 2012), (Ozkan } \\
\text { et al., 2011), (Ghodsypour \& O'Brien, 1998), (Benyoucef et al., 2003), (Kar \& Pani, 2014), (Garg } \\
\text { et al.), (Tang \& Jarmillo, 2005), (Pal et al., 2013), (Jain et al., 2013), (Valahzaghard et al., 2011), } \\
\text { (Jariyal \& Garg, 2012). }\end{array}$ \\
\hline & Discount on Product Cost & (Kar \& Pani, 2014), (Jain et al., 2013). \\
\hline \multirow{3}{*}{ Delivery } & Online Delivery Schedule & (Humphreys et al., 2001), (Valahzaghard et al., 2011). \\
\hline & Delivery Lead Time & $\begin{array}{l}\text { (çebi \& Bayraktar, 2003), (Prahinski \& Benton, (2004), (Pi \& Low, 2005), (Kreng \& Wang, 2005), } \\
\text { (Li et al., 2006), (Hsu et al., 2006), (Zhang et al., 2009), (Lee \& Amy, 2009), (Shemshadi et al., } \\
\text { 2011), (Liao \& Kao, 2011), (Vinodh et al., 2011). (Priya et al., 2012), (Kar \& Pani, 2014), (Garg et } \\
\text { al.), (Tang \& Jarmillo, 2005), (Ozkan et al., 2011), (Jain et al., 2013), (Valahzaghard et al., 2011). }\end{array}$ \\
\hline & Fulfilled order timely & $\begin{array}{l}\text { (Mentzer et al., 2001), (Akarte et al., 2001), (Ozkan et al., 2011), (Ghodsypour \& O'Brien, 1998), } \\
\text { (Benyoucef et al., 2003), (Kar \& Pani, 2014), (Garg et al.), (Tang \& Jarmillo, 2005), (Pal et al., } \\
\text { 2013), (Jain et al., 2013), (Valahzaghard et al., 2011), (Valahzaghard et al., 2011). }\end{array}$ \\
\hline \multirow{4}{*}{ Service } & Site Design & (DeLone \& McLean, 2003), (Valahzaghard et al., 2011). \\
\hline & Responsiveness & $\begin{array}{l}\text { (Parasuraman et al., 1988), (Ghodsypour \& O’Brien, 1998), (Kar \& Pani, 2014), (Ozkan et al., 2011), } \\
\text { (Valahzaghard et al., 2011), }\end{array}$ \\
\hline & Customer Support & $\begin{array}{l}\text { (Priya et al., 2012), (Ozkan et al., 2011), (Garg et al.), (Tang \& Jarmillo, 2005), (Valahzaghard et } \\
\text { al., 2011), (Valahzaghard et al.,2011). }\end{array}$ \\
\hline & Accessibility & $\begin{array}{l}\text { (Lancaster et al., 2006), (Ozkan et al., 2011), (Ghodsypour \& O'Brien, 1998), (Valahzaghard et al., } \\
\text { 2011). }\end{array}$ \\
\hline \multirow{5}{*}{ Flexibility } & Online order Track & (Lancaster et al., 2006), (Valahzaghard et al., 2011). \\
\hline & Reaction to demand Change & $\begin{array}{l}\text { (Young-Ybarra \& Wiersema, 1999), (Grewal \& Tansuhaj, 2001), (Chircu \& Kauffman, 2000), } \\
\text { (Narasimhan \& Kim, 2001), (Ozkan et al., 2011), (Ghodsypour \& O’Brien, 1998), (Garg et al.), } \\
\text { (Tang \& Jarmillo, 2005), (Jain et al., 2013), (Valahzaghard et al., 2011), (Valahzaghard et al.,2011). }\end{array}$ \\
\hline & IT infrastructure Flexibility & $\begin{array}{l}\text { (Wixom \& Watson, 2001), (Dai \& Kauffman, 2002), (Kim \& Narasimhan, 2002), (Valahzaghard et } \\
\text { al., 2011). }\end{array}$ \\
\hline & Capacity & (Tang \& Jarmillo, 2005). \\
\hline & Production Flexibility & (Kar \& Pani, 2014), (Jain et al., 2013). \\
\hline \multirow{4}{*}{ Trust } & Website Security & $\begin{array}{l}\text { (Fairchild et al., 2004), (Harland et al., 2007), (Jun \& Cai, 2003), (Phan \& Stata, 2002), (Soliman \& } \\
\text { Janz, 2004), (Tang \& Jarmillo, 2005), (Garg et al.), (Valahzaghard et al., 2011). }\end{array}$ \\
\hline & Reliability & $\begin{array}{l}\text { (Head \& Hassanein, 2002), (Becerra \& Gupta, 2003), (Ratnasingam \& Pavlou, 2003), (Garg et al.), } \\
\text { (Jain et al., 2013), (Valahzaghard et al., 2011). }\end{array}$ \\
\hline & Assurance & $\begin{array}{l}\text { (Schröder \& McEachern, 2002), (Manning et al., 2006), (Turner \& Davies, 2002), (Parasuraman et } \\
\text { al., 1988), (Kar \& Pani, 2014), (Pal et al., 2013), (Valahzaghard et al., 2011). }\end{array}$ \\
\hline & $\begin{array}{l}\text { Integrity, Benevolence, } \\
\text { Competence }\end{array}$ & $\begin{array}{l}\text { (Fairchild et al., 2004), (Harland et al., 2007), (Reichheld \& Schefter, 2000), (Soliman \& Janz, 2004), } \\
\text { (Garg et al.), (Valahzaghard et al., 2011). }\end{array}$ \\
\hline \multirow{3}{*}{$\begin{array}{l}\text { Past } \\
\text { Performance }\end{array}$} & E-Transaction & $\begin{array}{l}\text { (Mentzer et al., 2001), (Ahire \& Dreyfus, 2000), (Choi \& Eboch, 1998), (Eagly \& Chaiken, 1993), } \\
\text { (Park, 1999), (Pugliese, 2000), (Tracica, 2002), (Kar \& Pani, 2014), (Tang \& Jarmillo, 2005), } \\
\text { (Valahzaghard et al., 2011). }\end{array}$ \\
\hline & e- Commerce Capability & $\begin{array}{l}\text { (Barua et al., 2004), (Zhu \& Kraemer, 2002), (Coates \& McDermott, 2002), (Hausman et al., 2002), } \\
\text { (Williams et al., 2002), (Eisenhardt \& Martin, 2000), (Valahzaghard et al., 2011). }\end{array}$ \\
\hline & $\begin{array}{l}\text { Reputation \& Past Business } \\
\text { Record }\end{array}$ & $\begin{array}{l}\text { (Priya et al., 2012), (Kar \& Pani, 2014), (Garg et al.), (Benyoucef et al., 2003), (Ozkan et al., 2011), } \\
\text { (Pal et al., 2013), (Valahzaghard et al.,2011). }\end{array}$ \\
\hline Finance & & $\begin{array}{l}\text { (Valahzaghard et al., 2011), (Vinodh et al., 2011), (Chang et al., 2011), (Deng \& Chan, 2011), (Tsai } \\
\text { et al., 2010), (Kilincci \& Onal, 2011), (Chen et al., 2006), (Yang \& Chen, 2006), (Bottani \& Rizzi, } \\
\text { 2006), (Benyoucef et al., 2003), (Kar \& Pani, 2014), (Ozkan et al., 2011), (Pal et al., 2013), } \\
\text { (Valahzaghard et al.,2011). }\end{array}$ \\
\hline \multirow{3}{*}{ Facility } & IT Equipment Capabilities & $\begin{array}{l}\text { (Benantar, 2001), (Benassi, 1999), (Dinnie, 1999), (Friedman, 2000), (Railsback, 2001), (Kar \& } \\
\text { Pani, 2014), (Valahzaghard et al., 2011). }\end{array}$ \\
\hline & $\begin{array}{l}\text { Production Equipment \& } \\
\text { Technological Capabilities }\end{array}$ & $\begin{array}{l}\text { (Weber et al., 1991), (Petroni \& Braglia, 2000), (Muralidharan et al., 2001), (Ha \& Krishnan, 2008), } \\
\text { (Tsai et al., 2010), (Akarte et al., 2001), (Ozkan et al., 2011), (Benyoucef et al., 2003), (Kar \& Pani, } \\
\text { 2014), (Tang \& Jarmillo, 2005), (Pal et al., 2013), (Valahzaghard et al., 2011), (Valahzaghard et al., } \\
\text { 2011). }\end{array}$ \\
\hline & R \& D Facility & $\begin{array}{l}\text { (Tang \& Jarmillo, 2005), (Benyoucef et al., 2003), (Kar \& Pani, 2014), (Ozkan et al., 2011), (Garg } \\
\text { et al.), (Valahzaghard et al. 2011). }\end{array}$ \\
\hline Location & & $\begin{array}{l}\text { (Aksoy \& Öztürk, 2011), (Kilincci \& Onal, 2011), (Tsai et al., 2010), (Mohammady Garfamy, 2006), } \\
\text { (Yang \& Chen, 2006), (Ireton, 2007), (Kar \& Pani, 2014), (Garg et al.), (Tang \& Jarmillo, 2005), } \\
\text { (Benyoucef et al., 2003), (Pal et al., 2013), (Valahzaghard et al.,2011). }\end{array}$ \\
\hline $\begin{array}{l}\text { Organizational } \\
\text { Structure }\end{array}$ & Communication Capabilities & $\begin{array}{l}\text { (Priya et al., 2012), (Ozkan et al., 2011), (Kar \& Pani, 2014), (Benyoucef et al., 2003), (Valahzaghard } \\
\text { et al.,2011). }\end{array}$ \\
\hline
\end{tabular}




\section{2.e-supplier selection technique}

The selection of the best evaluation method is very important task in a supply chain for fulfilling different objectives. There were several objectives in the traditional supply chain like maximization of profit, minimization of cost, improving quality. Traditional literature ranges from the single objective method for multi- objective linear programming model (Ghodsypour \& O'Brien, 1998). The objectives of e- supplier selection is also similar to the traditional supply chain such as improving quality, reducing cost, and increasing profit. The supplier selection method in traditional SCM has been same just like esupplier selection (Kara, 2011). Multi criteria decision making approach and mathematical programming model are adopted by most of researchers in the literature. Fuzzy TOPSIS and two-stage stochastic programming were developed for supplier selection by Kara (2011). Fuzzy analytical hiararch process (AHP) approach for supplier selection in manufacturing washing machine was preferred by Kilincci and Onal (2011). Fuzzy analytic network process for supplier selection was used by Vinodh et al. (2011) in manufacturing organizations. A Hierarchy MCDM model based on fuzzy set theory and VIKOR method was proposed to deal with the supplier used by Sanayei et al. (2010). There are various techniques used and some of them had been explained earlier. The different techniques used in literature for supplier selection are given in the Table 2.

\section{Table 2}

Sources of e-supplier selection methodology

\begin{tabular}{|c|c|}
\hline Methodology & References \\
\hline Delphi & (Valahzaghard et al., 2011), (Kar \& Pani, 2014). \\
\hline Fuzzy MADM & (Valahzaghard et al., 2011). \\
\hline Fuzzy VIKOR & Valahzaghard et al., 2011), (Shemshadi, 2011). \\
\hline Fuzzy Delphi & (Valahzaghard et al., 2011). \\
\hline Fuzzy TOPSIS & $\begin{array}{l}\text { (Chen et al., 2006), (Liao \& kao, 2011), (Deng \& Chan, 2011), (Kilic, 2013), } \\
\text { (Junior et al., 2014), (Luthra et al., 2016). }\end{array}$ \\
\hline ANOVA & (Kar \& Pani, 2014). \\
\hline ANP & (Lin et al., 2011). \\
\hline OLAP using SPSS & (Priya et al., 2012). \\
\hline AHP & $\begin{array}{l}\text { (Akarte et al., 2001), (Tang \& Jarmillo, 2005), (Benyoucef et al., 2003), (Ozkan et } \\
\text { al., 2011), (Ghodsypour \& O’Brien, 1998), (Bhutia \& O’Brien, 2012), } \\
\text { (Muralidharan et al., 2002), (Garg et al., 2014), (Shakey, 2006). }\end{array}$ \\
\hline Linear Programming & (Lin et al., 2011), (Ghodsypour \& O’Brien, 1998), (Kilic, 2013). \\
\hline Fuzzy AHP & $\begin{array}{l}\text { (Jain et al., 2013), (Chamodrakas \& Batis, 2010), (Sevkli \& Koh, 2008), } \\
\text { (Valahzaghard et al., 2011), (Lee \& Amy 2009), (Ho Ha \& Krishnan, 2008), (Chan } \\
\text { \& Kumar, 2007), (chan et al., 2008), (Kahraman et al., 2003). }\end{array}$ \\
\hline TOPSIS & (Lin et al., 2011), (Bhutia \& Phipon, 2012), (Junior et al., 2014). \\
\hline SIR. VIKOR & (Valahzaghard et al., 2011). \\
\hline MCDM-Matrix method & (Jarial \& Garg, 2012)( Garg et al., 2010). \\
\hline Distance Based Approximation & $\begin{array}{l}\text { (Kumar \& Garg , 2010),(Gupta Amit, 2014),( kumar \& Garg., 2013), (Garg et al., } \\
\text { 2010). }\end{array}$ \\
\hline Multi Choice Goal Programming & (Liao \& Kao, 2011). \\
\hline Data Envelopment Analysis & (Ho Ha \& Krishnan, 2008). \\
\hline Neural Network & (Ho Ha \& Krishnan, 2008). \\
\hline Fuzzy Approach & (Junior et al., 2013), (Chan et al., 2004). \\
\hline Fuzzy DEMTEL & (Chang et al., 2011). \\
\hline
\end{tabular}

\section{Methodology Adopted}

\subsection{Modified Distance Based Approach}

Specifying the ideally perfect value of attributes in the procedure and defining the optimum state of overall objective are the points of consideration for the growth of Distance Based Approximation approach (DBA). In this study, optimum e-supplier selection is the optimal state of objective. The distance based approximation approach has earlier been used for optimal selection of software reliability growth models (Sharma et al., 2010); grading and selection of robots (Garg et al., 2010) and optimal selection of commercial off-the-shelf, etc. (Garg et al., 2017). The effects of weight can be easily accommodated by distance based approach for ranking the various criteria used to rank different 
attributes. The value of the composite distance of alternative e-supplier from optimal value can be determined by modified distance based approach. e-suppliers rankings are performed in ascending/ descending order on the basis of composite distance value from the optimal value i.e. zero. The MDBA is explained below in the following steps. The set of attributes, presenting the performance rating of each alternate e-supplier against each ranking criterion can be represented by the following criteria matrix:

$$
\left[x_{i j}\right]=\left[\begin{array}{cccc}
x_{11} & x_{12} & \cdots & x_{1 j} \\
x_{21} & x_{22} & \cdots & x_{2 j} \\
\vdots & \vdots & \ddots & \vdots \\
x_{i 1} & x_{i 2} & \cdots & x_{i j} \\
x_{o p 1} & x_{o p 2} & \cdots & x_{o p j}
\end{array}\right],
$$

Here, $i \quad(i=1,2, \ldots \ldots \ldots n)$, and $j \quad(j=1,2, \ldots \ldots \ldots . . m)$ represent the number of e-suppliers and e-supplier selection criteria, respectively. Here, $x_{i j}$ represents the weight of $i^{\text {th }}$ supplier for $j^{\text {th }}$ criteria and $x_{o p j}$ gives the optimal value for any particular criteria among all available alternatives of e-suppliers.

$$
[z]=\left[\begin{array}{cccc}
z_{11} & z_{12} & \cdots & z_{1 m} \\
z_{21} & z_{22} & \cdots & z_{2 m} \\
\vdots & \vdots & \vdots & \vdots \\
z_{n 1} & z_{n 2} & \cdots & z_{n m} \\
z_{o p 1} & z_{o p 2} & \cdots & z_{o p m}
\end{array}\right],
$$

where

$$
\begin{aligned}
z_{i j} & =\frac{x_{i j}-\overline{x_{j}}}{S_{j}}, \\
\overline{x_{j}} & =\frac{1}{n} \sum_{i=1}^{n} x_{i j}, \\
S_{j} & =\left[\frac{1}{n} \sum_{i=1}^{n}\left(x_{i j}-\bar{x}_{j}\right)\right]^{1 / 2},
\end{aligned}
$$

where; $\mathrm{n}=$ Number of e-supplier selection criteria; $\mathrm{X}_{i j}=$ Indicator value of alternative e-supplier $I$ for criteria $j$ and $\mathrm{S}_{j}=$ Standard deviation of criteria of $j$. In the next step, we find the distance or difference from each criterion to the reference point, which is achieved by subtracting the optimal value from the corresponding element. Next step is to introduce the performance rating difference of each e-supplier selection criteria by representing the aggregated preference weight and the final weighted distance matrix given by

$$
[W]=\left[\begin{array}{cccc}
w_{11} & w_{12} & \cdots & w_{1 j} \\
w_{21} & w_{22} & \cdots & w_{2 j} \\
\cdots & \cdots & \cdots & \cdots \\
w_{i 1} & w_{i 2} & \cdots & w_{i j}
\end{array}\right],
$$

where

$$
\mathrm{W}_{i j}=\left(\mathrm{z}_{\text {opj }}-\mathrm{z}_{i j}\right) w_{j} \text {, }
$$

and $w_{j}$ represents the weight of the $j^{\text {th }}$ criterion. Finally Euclidean composite distance value between each e- supplier is derived from:

$\mathrm{CD} i=\left[\sum_{j=1}^{m}\left\{\left(z_{o p j}-z_{i j}\right) w_{j}\right\}^{2}\right]^{1 / 2}$.

The composite distances generally define the gap or difference between the each of two available alternatives of the e-supplier. It is also termed as a mathematical expression of several dimensions in which each alternative e-supplier can be compared. 


\section{Ranking and Selection Procedure}

\subsection{Identification of E-supplier}

Supply chain management has become a crucial task now days and for better handling e-supply chain is mostly used in business. This research work is mainly concentrated over finding and ranking the available e-suppliers. This paper actually includes a case study of a firm which mainly manufactures the exhaust system for both 2-wheelers and 4-wheelers. This is a Japan Indian private limited firm established in India in 2003 in Bawal, Rewari. It is an ISO 14001, OSHAS and TS certified company. It is the key and sole supplier for global brands like Suzuki, Honda, Yamaha, and Daikin. This firm received the supply from the four different e-suppliers for the same component. So, this paper actually will give the ranking to these four available e-suppliers.

\subsection{E-supplier Selection Criteria: Identification and selection}

There are many criteria and sub-criteria available in the open literature which tabulated earlier in the literature survey. The researcher during the selection of the criteria or sub-criteria mainly focused on characteristics like quality, cost, service etc. which are closely related to the mechanical manufacturing sector. Each of the criteria is important in a specific manner and related to e-supplier selection and useful for fulfilling the objective of this research work.

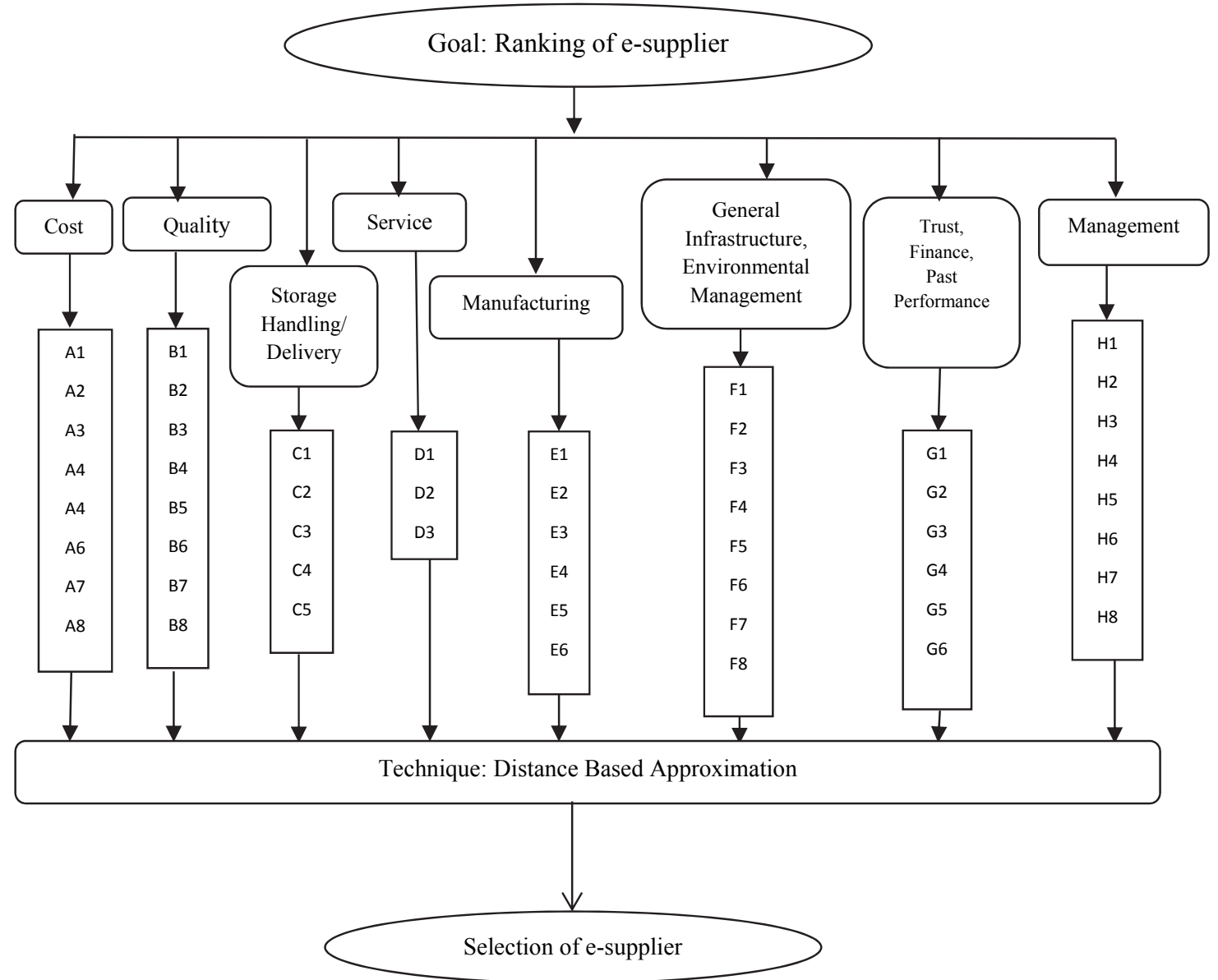

Fig. 1. Hierarchical structure of E- supplier selection \& ranking criteria

By collecting the data from the literature and the experts' opinion, 52 sub- criteria have been finalized and grouped into 8 categories, namely (1) cost (2) quality (3) storage Handling/Delivery (4) Service (5) Manufacturing (6) General, infrastructure \& Environmental Management (7) Trust, Finance \& Past Performance (8) Management. E-supplier selection criteria are arranged in a hierarchical structure in Fig. 1. The e-supplier selection criteria which include in this research seems to be sufficient for achieving the goal, i.e. ranking of e-suppliers. 


\subsection{Experts Identification \& Selection}

With the lack of experience and maturity in the area of e-supply chain, it becomes impossible to identify the relevant data available in the open literature that would be favorable for e-supplier selection and their ranking. So, researchers first study the open literature and collect the primary data available seems to be dealing with the e-supplier selection criteria. To find out the relevance of the data the researchers took the assistance of experts from the manufacturing industry and academia that have sufficient experience in supply chain for dealing with e-supplier selection problems. This study includes only those experts who are dealing with the mechanical manufacturing sector. Optimal data collection was done only after considering the expert's opinion. An expert with having the perfect knowledge in their field is alone sufficient for elicitation process. But it is better to have more than one expert in avoiding mistakes due to limited knowledge. The researchers selected their experts on the basis of publications, experience in the area of e- supplier selection while working in any institutions or industry, capability and versatility for handling various issues.

\subsection{Questionnaire Design}

The researchers fabricated the questionnaire for data collection of exploratory survey. Before preparing the questionnaire, the researchers with expert's assistance first scrutinized the primary data and excluded the data which was found irrelevant in mechanical manufacturing e-supplier selection area. On the basis of relevant data remained after initial screening, researchers prepared the questionnaire. Single Questionnaire is designed by considering equal weightage to all the ranking criteria. This questionnaire is designed to get the performance or ranking of each e-supplier based on all criteria. This questionnaire was forwarded to experts in online and offline basis. Google drive is used for forwarding the questionnaire for online mode. This questionnaire prepared into three segments: first part consists of a covering letter for describing the aim of the study and statement of confidentiality. The second part covers the demographic detail, e.g. company name, contact person name and their details. Third part consists of ranking criteria for assigning weights/ performance ratings of e-supplier selection.

\subsection{Data collection and Analysis}

The tests were performed for examining the reliability of the data obtained from experts using SPSS. The obtained value of Cronbach alpha was higher than 0.8 for the ranking and the performance ratings of e-suppliers on the basis of e-supplier selection criteria. This value of Cronbach alpha shows the level of reliability and internal consistency in between the expert's opinion. Later on, the ANOVA test was performed for comparing the means and to find out the mean variance for all e-suppliers. These entire statistical tests performed on aggregated expert's opinion and not on any individual opinion. All experts were considered equally weighted in terms of their competency, qualification and experience with negligible difference observed in terms of importance and credibility.

\subsection{Performance Rating of e-supplier}

The performance rating of four e-suppliers are decided on the basis of expert's opinion aggregation and ranking. All 4 e-suppliers average aggregated ratings given by experts' are given in Table 3.

\section{Table 3}

Aggregated Average Performance Ratings of e-suppliers

\begin{tabular}{|c|c|c|c|c|}
\hline Criteria & e-supplier: 1 & e-supplier: 2 & e-supplier: 3 & e-supplier: 4 \\
\hline Cost & 3.7 & 3.775 & 2.9 & 4.025 \\
\hline Quality & 4.175 & 2.1 & 3.175 & 4.15 \\
\hline Storage Handling / Delivery & 4.28 & 2.4 & 3.12 & 4.68 \\
\hline Service & 3.67 & 3.4 & 2.54 & 4.27 \\
\hline Manufacturing & 4.47 & 2.45 & 2.87 & 4.47 \\
\hline General, Infrastructure, Environmental Mgt. & 4.58 & 2.53 & 3.43 & 3.075 \\
\hline Trust, Finance, Past Performance & 5 & 3.07 & 3.77 & 2.7 \\
\hline Management & 4.6 & 3.025 & 3.25 & 4.5 \\
\hline
\end{tabular}




\subsection{Ranking and selection}

The composite distance or preference index shows the closeness of each alternative e-supplier with respect to other e-supplier with the optimal solution by using the DBA method as described in section 3. On the basis of composite distance values these alternative e-suppliers are arranged in ascending/descending order. The first ranking assigned to e-supplier who has least composite distance value. The decision makers take the final decision after considering the various practical constraints, e.g. political, social and management.

\section{Model Demonstration}

For demonstration and validation of proposed DBA application for ranking of e-suppliers are done by taking an example of ranking and selection of e-supplier for web based supply chain. This example in which 4 e-suppliers are ranked on the basis of 52 sub-criteria grouped in 8 major categories. The esupplier selection criteria are described in Fig. 1. The weights of all e-supplier selection criteria are considered equal. The performance ratings of all major 8 groups are given in Table 3 . There are still many scopes to include other e-supplier selection criteria and e-suppliers based on the problem and priority of decision makers. The main aim behind the demonstration is to check the suitability of this model and development of an effective model application procedure. The DBA applied the ranking of 4 e- supplier is based on 8 criteria, i.e. Quality, Storage, Cost, Service, Manufacturing, General infrastructure environmental Management, Trust finance past performance, Management. The criteria matrix $x_{i j}$ is given as:

$$
\left[x_{i j}\right]=\left[\begin{array}{cccccccc}
3.7 & 4.175 & 4.28 & 3.67 & 4.47 & 4.58 & 5 & 4.6 \\
3.775 & 2.1 & 2.4 & 3.4 & 2.45 & 2.53 & 3.07 & 3.025 \\
2.9 & 3.175 & 3.12 & 2.54 & 2.87 & 3.43 & 3.77 & 3.25 \\
4.025 & 4.15 & 4.68 & 4.27 & 4.47 & 3.075 & 2.7 & 4.5 \\
2.9 & 2.1 & 2.4 & 2.54 & 2.45 & 2.53 & 2.7 & 3.025
\end{array}\right]
$$

From Eqs. (4-5), the attributes' average and standard deviation values are 0.7, 1.32, 1.22, 0.93, 1.12, $0.87,0.94,0.82$ and $0.422,0.86,0.91,0.623,0.92,0.751,0.88,0.712$. The $[\mathrm{Z}]$ and $[\mathrm{w}]$ are as follows,

$$
[\mathrm{z}]=\left[\begin{array}{cccccccc}
0.237 & 0.880 & 0.725 & 0.321 & 0.978 & 1.571 & 1.55 & 1.060 \\
0.415 & -1.535 & -1.341 & -0.112 & -1.217 & -1.159 & -0.648 & -1.152 \\
-1.659 & -0.256 & -0.55 & -1.493 & -0.761 & 0.04 & 0.148 & -0.836 \\
1.007 & 0.907 & 1.165 & 1.284 & 0.978 & 0.433 & -1.07 & 0.920
\end{array}\right] \quad[\mathrm{W}]=\left[\begin{array}{cccccccc}
0.593 & 0.000729 & 0.1936 & 0.9274 & 0 & 0 & 0 & 0 \\
0.351 & 5.963 & 6.298 & 1.95 & 4.818 & 7.453 & 4.83 & 4.893 \\
7.129 & 1.353 & 2.941 & 7.712 & 3.024 & 2.344 & 1.966 & 3.595 \\
0 & 0 & 0 & 0 & 0 & 4.016 & 6.86 & 0.20
\end{array}\right]
$$

The values of composite distance are given in Table 4.

Table 4

Overall Ranking of E- Suppliers

\begin{tabular}{lcccc}
\hline e- Suppliers & S1 & S2 & S3 & S4 \\
\hline Sum & 1.71473 & 36.538 & 30.064 & 10.896 \\
Composite Distance (CD) & 1.3095 & 6.045 & 5.4831 & 3.3009 \\
Ranking & 1 & 4 & 3 & 2 \\
\hline
\end{tabular}

The composite distance value of alternate e-supplier based on eight criteria for ranking individually considering the ranking criteria is determined by using DBA methodology. The CD values and ranking of e-suppliers based on individual criteria are given in Table 5.

Table 5

\begin{tabular}{|c|c|c|c|c|c|c|c|c|c|c|c|c|c|c|c|c|}
\hline \multirow[t]{2}{*}{ e-Suppliers } & \multicolumn{2}{|l|}{ COST } & \multicolumn{2}{|l|}{ Quality } & \multicolumn{2}{|c|}{$\begin{array}{l}\text { Delivery/ } \\
\text { Handling }\end{array}$} & \multicolumn{2}{|l|}{ Service } & \multicolumn{2}{|c|}{ Manufacturing } & \multicolumn{2}{|c|}{$\begin{array}{l}\text { General, } \\
\text { Infrastructure }\end{array}$} & \multicolumn{2}{|c|}{$\begin{array}{l}\text { Trust, Finance, } \\
\text { Past } \\
\text { Performance }\end{array}$} & \multicolumn{2}{|c|}{ Management } \\
\hline & $\begin{array}{l}\text { CD } \\
\text { Value }\end{array}$ & 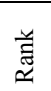 & $\begin{array}{l}\text { CD } \\
\text { Value }\end{array}$ & 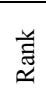 & $\begin{array}{l}\text { CD } \\
\text { Value }\end{array}$ & $\begin{array}{l}\text { 铓 }\end{array}$ & $\begin{array}{l}\text { CD } \\
\text { Value }\end{array}$ & 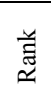 & $\begin{array}{l}\text { CD } \\
\text { Value }\end{array}$ & 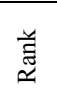 & $\begin{array}{l}\text { CD } \\
\text { Value }\end{array}$ & $\begin{array}{l}\text { 䔍 } \\
\text { N }\end{array}$ & $\begin{array}{l}\text { CD } \\
\text { Value }\end{array}$ & 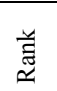 & $\begin{array}{l}\text { CD } \\
\text { Value }\end{array}$ & 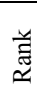 \\
\hline S1 & 4.353 & 3 & 1.840 & 1 & 1.545 & 2 & 2.258 & 2 & 0.953 & 1 & 0.396 & 1 & 0 & 1 & 1.529 & 1 \\
\hline S2 & 3.863 & 2 & 7.345 & 4 & 5.551 & 4 & 3.380 & 3 & 5.892 & 4 & 6.415 & 4 & 5.064 & 3 & 6.724 & 4 \\
\hline S3 & 6.036 & 4 & 4.344 & 3 & 3.795 & 3 & 4.151 & 4 & 4.867 & 3 & 4.286 & 2 & 3.442 & 4 & 5.920 & 3 \\
\hline S4 & 3.21 & 1 & 2.631 & 2 & 0.482 & 1 & 0.966 & 1 & 1.272 & 2 & 5.483 & 3 & 6.079 & 2 & 2.218 & 2 \\
\hline
\end{tabular}

Category wise E-suppliers Ranking Results 


\section{Methodology Validation}

For the validation of the results obtained from the proposed DBA approach, the same problem was also resolved using other techniques like TOPSIS (Lin et al., 2003), Matrix method (Jarial \& Garg, 2012) and AHP (Ghodsypour \& O'Brien, 1998). The final ranking obtained for four suppliers, namely S1, S2, S3, and S4, based on eight criteria using DBA, TOPSIS, Matrix and AHP were estimated and compared. The comparisons show that the results of the proposed methodology are similar to the results given by other three methods.

\section{Results}

According to adopted methodology, the lower composite distance value shows the best alternate of esuppliers. Fig. 2 shows the ranking of all four e- suppliers based on eight criteria, namely Cost, Quality, Delivery, Service, Manufacturing, General infrastructure, Trust finance past performance and Management.

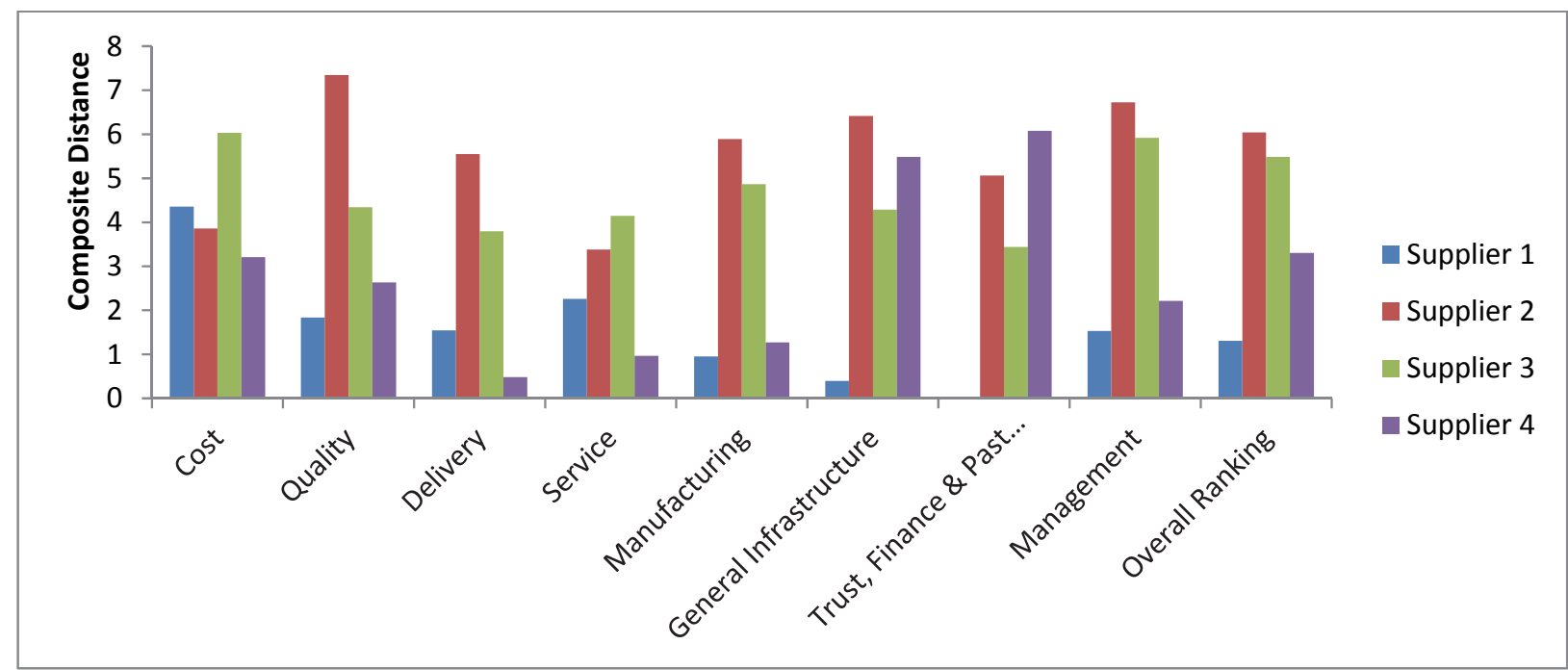

Fig. 2. Ranking of e-Suppliers

This chart shows that e-supplier no 1 (S1) is ranked no $1 \&$ supplier 3 (S3), Supplier 4 (S4) ranked no. $3 \& 2$ in Manufacturing based on composite distance value. So, by this chart, it is easy to identify ranking of all four e-suppliers by considering individual criteria. It also depicts the aggregate ranking of e- suppliers by considering all criteria together. So, on the basis of overall ranking e- supplier no-1 ranked 1 and e-supplier-2 ranked 4 as depicted in the end of this chart.

\section{Conclusion}

The major issues rising due to e-supply chain in e-supplier selection process was mainly covered by this paper. e- Supplier selection was a multi-criteria decision problem. The final decision has been achieved only by considering a set of various e-supplier selection criteria. Distance based approximation approach was applied only after identification of all comparison criteria. The proposed methodology allows the Decision makers to select ranking criteria according to their preference. This model has enabled to rank various e- suppliers based on a number of criteria taken simultaneously. DBA approach is quite efficient, less time consuming and most suitable for solving multi criteria decision problem than TOPSIS, AHP and matrix method. It is a simple mathematical calculation and matrix operation and hence quiet useful approach for solving ranking problem. 


\section{References}

Ahire, S. L., \& Dreyfus, P. (2000). The impact of design management and process management on quality: an empirical investigation. Journal of Operations Management, 18(5), 549-575.

Akarte, M. M., Surendra, N. V., Ravi, B., \& Rangaraj, N. (2001). Web based casting supplier evaluation using analytical hierarchy process. Journal of the Operational Research Society, 52(5), 511-522.

Aksoy, A., \& Öztürk, N. (2011). Supplier selection and performance evaluation in just-in-time production environments. Expert Systems with Applications, 38(5), 6351-6359.

Barua, A., Konana, P., Whinston, A. B., \& Yin, F. (2004). An empirical investigation of net-enabled business value. MIS quarterly, 28(4), 585-620.

Becerra, M., \& Gupta, A. K. (2003). Perceived trustworthiness within the organization: The moderating impact of communication frequency on trustor and trustee effects. Organization Science, 14(1), 3244.

Benantar, M. (2001). The Internet public key infrastructure. IBM Systems Journal, 40(3), 648-665.

Benassi, P. (1999). TRUSTe: an online privacy seal program. Communications of the ACM, 42(2), 5659.

Benyoucef, L., Ding, H., \& Xie, X. (2003). Supplier selection problem: selection criteria and methods (Doctoral dissertation, INRIA).

Bhutia, P. W., \& Phipon, R. (2012). Application of AHP and TOPSIS method for supplier selection problem. IOSR Journal of Engineering, 2(10), 43-50.

Bottani, E., \& Rizzi, A. (2006). A fuzzy TOPSIS methodology to support outsourcing of logistics services. Supply Chain Management: An International Journal, 11(4), 294-308.

Chamodrakas, I., Batis, D., \& Martakos, D. (2010). Supplier selection in electronic marketplaces using satisficing and fuzzy AHP. Expert Systems with Applications, 37(1), 490-498.

Çebi, F., \& Bayraktar, D. (2003). An integrated approach for supplier selection. Logistics Information Management, 16(6), 395-400.

Chan, F. T., Kumar, N., Tiwari, M. K., Lau, H. C., \& Choy, K. L. (2008). Global supplier selection: a fuzzy-AHP approach. International Journal of Production Research, 46(14), 3825-3857.

Chan, F. T., \& Kumar, N. (2007). Global supplier development considering risk factors using fuzzy extended AHP-based approach. Omega, 35(4), 417-431.

Chang, B., \& Hung, H. F. (2010). A study of using RST to create the supplier selection model and decision-making rules. Expert Systems with Applications, 37(12), 8284-8295.

Chang, S. L., Wang, R. C., \& Wang, S. Y. (2007). Applying a direct multi-granularity linguistic and strategy-oriented aggregation approach on the assessment of supply performance. European Journal of Operational Research, 177(2), 1013-1025.

Chang, B., Chang, C. W., \& Wu, C. H. (2011). Fuzzy DEMATEL method for developing supplier selection criteria. Expert systems with Applications, 38(3), 1850-1858.

Chen, C. T., Lin, C. T., \& Huang, S. F. (2006). A fuzzy approach for supplier evaluation and selection in supply chain management. International Journal of Production Economics, 102(2), 289-301.

Chircu, A. M., \& Kauffman, R. J. (2000). Limits to value in electronic commerce-related IT investments. Journal of Management Information Systems, 17(2), 59-80.

Choi, T. Y., \& Eboch, K. (1998). The TQM paradox: relations among TQM practices, plant performance, and customer satisfaction. Journal of Operations Management, 17(1), 59-75.

Coates, T. T., \& McDermott, C. M. (2002). An exploratory analysis of new competencies: a resource based view perspective. Journal of Operations Management, 20(5), 435-450.

Dai, Q., \& Kauffman, R. J. (2002). B2B e-commerce revisited: Leading perspectives on the key issues and research directions. Electronic Markets, 12(2), 67-83.

Delone, W. H., \& McLean, E. R. (2003). The DeLone and McLean model of information systems success: a ten-year update. Journal of Management Information Systems, 19(4), 9-30. 
Deng, Y., \& Chan, F. T. (2011). A new fuzzy dempster MCDM method and its application in supplier selection. Expert Systems with Applications, 38(8), 9854-9861.

Dinnie, G. (1999). The second annual global information security survey. Information Management \& Computer Security, 7(3), 112-120.

Eagly, A. \&. (1993). New York. The Psychology of Attitudes.

Eisenhardt, K. M., \& Martin, J. A. (2000). Dynamic capabilities: what are they?. Strategic Management Journal, 21(10-11), 1105-1121.

Fairchild, A. M., Ribbers, P. M., \& Nooteboom, A. O. (2004). A success factor model for electronic markets: Defining outcomes based on stakeholder context and business process. Business Process Management Journal, 10(1), 63-79.

Friedman, B., Khan Jr, P. H., \& Howe, D. C. (2000). Trust online. Communications of the ACM, 43(12), 34-40.

Garg, D., Luthra, S., \& Haleem, A. (2014). Ranking of performance measures of GSCM towards sustainability: using analytic hierarchy process. International Journal of Social, Human Science and Engineering, 8(3), 764-770.

Garg, R., Sharma, K., Kumar, R., \& Garg, R. K. (2010). Performance analysis of software reliability models using matrix method. World Academy of Science, Engineering and Technology, 71, 31-38.

Gary Teng, S., \& Jaramillo, H. (2005). A model for evaluation and selection of suppliers in global textile and apparel supply chains. International Journal of Physical Distribution \& Logistics Management, 35(7), 503-523.

Ghodsypour, S. H., \& O'Brien, C. (1998). A decision support system for supplier selection using an integrated analytic hierarchy process and linear programming. International Journal of Production Economics, 56, 199-212.

Grewal, R., \& Tansuhaj, P. (2001). Building organizational capabilities for managing economic crisis: The role of market orientation and strategic flexibility. Journal of Marketing, 65(2), 67-80.

Ha, S. H., \& Krishnan, R. (2008). A hybrid approach to supplier selection for the maintenance of a competitive supply chain. Expert Systems With Applications, 34(2), 1303-1311.

Harland, C. M., Caldwell, N. D., Powell, P., \& Zheng, J. (2007). Barriers to supply chain information integration: SMEs adrift of eLands. Journal of Operations Management, 25(6), 1234-1254.

Hausman, W. H., Montgomery, D. B., \& Roth, A. V. (2002). Why should marketing and manufacturing work together? Some exploratory empirical results. Journal of Operations Management, 20(3), 241257.

Head, M. M., \& Hassanein, K. (2002). Trust in e-commerce: Evaluating the impact of third-party seals. Quarterly Journal of Electronic Commerce, 3, 307-326.

Hsu, C. C., Kannan, V. R., Keong Leong, G., \& Tan, K. C. (2006). Supplier selection construct: instrument development and validation. The International Journal of Logistics Management, 17(2), 213-239.

Humphreys, P. K., Lai, M. K., \& Sculli, D. (2001). An inter-organizational information system for supply chain management. International Journal of Production Economics, 70(3), 245-255.

Ireton, S. (2007). Global sourcing checklist. Industry Week, 40.

Jain, V., Tiwari, M. K., \& Chan, F. T. S. (2004). Evaluation of the supplier performance using an evolutionary fuzzy-based approach. Journal of Manufacturing Technology Management, 15(8), 735-744.

Jarial, S. K., \& Garg, R. K. (2012). Ranking of vendors based on criteria by MCDM-matrix method-a case study for commercial vehicles in an industry. International Journal of Latest Resource Science and Technology, 1(4), 337-341.

Jain, R., Singh, A. R., \& Mishra, P. K. (2013). Prioritization of supplier selection criteria: A fuzzyAHP approach. MIT International Journal of Mechanical Engineering, 3(1), 34-42. 
Jariyal, S.K., \& Garg, R.K. (2012). Vendor selection criteria and and methods. International Journal of Electrical, Electronics and Mechanical Fundamentals, 1(1).

Johnson, M., \& Whang, S. (2002). E-business and supply chain manmanagement: an overview. Production and Operations Management, 11,413-423.

Jun, M., \& Cai, S. (2003). Key obstacles to EDI success: from the US small manufacturing companies' perspective. Industrial Management \& Data Systems, 103(3), 192-203.

Junior, F. R. L., Osiro, L., \& Carpinetti, L. C. R. (2013). A fuzzy inference and categorization approach for supplier selection using compensatory and non-compensatory decision rules. Applied Soft Computing, 13(10), 4133-4147.

Junior, F. R. L., Osiro, L., \& Carpinetti, L. C. R. (2014). A comparison between Fuzzy AHP and Fuzzy TOPSIS methods to supplier selection. Applied Soft Computing, 21, 194-209.

Kara, S. S. (2011). Supplier selection with an integrated methodology in unknown environment. Expert Systems with Applications, 38(3), 2133-2139.

Kahraman, C., Cebeci, U., \& Ulukan, Z. (2003). Multi-criteria supplier selection using fuzzy AHP. Logistics Information Management, 16(6), 382-394.

Kerney, A. (2005). Public Sector Procurement Survey. Transforming Public Services, pp.24-25.

Kilic, H. S. (2013). An integrated approach for supplier selection in multi-item/multi-supplier environment. Applied Mathematical Modelling, 37(14-15), 7752-7763.

Kilincci, O., \& Onal, S. A. (2011). Fuzzy AHP approach for supplier selection in a washing machine company. Expert systems with Applications, 38(8), 9656-9664.

Kim, S. W., \& Narasimhan, R. (2002). Information system utilization in supply chain integration efforts. International Journal of Production Research, 40(18), 4585-4609.

Kreng, V. B., \& Wang, I. C. (2005). Supplier management for manufacturer-a case study of flexible PCB. The International Journal of Advanced Manufacturing Technology, 25(7-8), 785-792.

Kumar Kar, A., \& K. Pani, A. (2014). Exploring the importance of different supplier selection criteria. Management Research Review, 37(1), 89-105.

Kumar, R., \& Garg, R. K. (2010). Optimal selection of robots by using distance based approach method. Robotics and Computer-Integrated Manufacturing, 26(5), 500-506.

Lancaster, S., Yen, D. C., \& Ku, C. Y. (2006). E-supply chain management: an evaluation of current web initiatives. Information Management \& Computer Security, 14(2), 167-184.

Lee, A. H. (2009). A fuzzy supplier selection model with the consideration of benefits, opportunities, costs and risks. Expert Systems with Applications, 36(2), 2879-2893.

Li, S., Madhok, A., Plaschka, G., \& Verma, R. (2006). Supplier-switching inertia and competitive asymmetry: A demand-side perspective. Decision Sciences, 37(4), 547-576.

Liao, C. N., \& Kao, H. P. (2011). An integrated fuzzy TOPSIS and MCGP approach to supplier selection in supply chain management. Expert Systems with Applications, 38(9), 10803-10811.

Lin, C. T., Chen, C. B., \& Ting, Y. C. (2011). An ERP model for supplier selection in electronics industry. Expert Systems with Applications, 38(3), 1760-1765.

Luthra, S., Kumar, S., Garg, D., \& Haleem, A. (2016). Comparative evaluation of GSCM practices in automotive components manufacturing firms of India: a fuzzy TOPSIS approach. International Journal of Logistics Systems and Management, 25(3), 358-390.

Manning, L., Baines, R. N., \& Chadd, S. A. (2006). Quality assurance models in the food supply chain. British Food Journal, 108(2), 91-104.

Mehmet Sevkli, S.C. Lenny Koh (2008). Hybrid analytical hierarchy process model for supplier selection. Industrial Management \& Data Systems, ol. 108 No. 1, 122-142.

Mentzer, J. T., Flint, D. J., \& Hult, G. T. M. (2001). Logistics service quality as a segment-customized process. Journal of Marketing, 65(4), 82-104. 
M.K. Valahzaghard, Mehdi Taghavi, Mostafa Memarzade (2011). E- Supplier Selectionintegrating Delphi and Fuzzy MADM. American Journal of Scientific Research, 40(2011), 85-111.

Mohammady Garfamy, R. (2006). Supplier selection and business process improvement doctoral thesis. University of Barcelona.

Muralidharan, C., Anantharaman, N., \& Deshmukh, S. G. (2002). A multi-criteria group decisionmaking model for supplier rating. Journal of Supply Chain Management, 38(3), 22-33.

Narasimhan, R., \& Kim, S. W. (2001). Information system utilization strategy for supply chain integration. Journal of Business Logistics, 22(2), 51-75.

Pal, O., Gupta, A. K., \& Garg, R. K. (2013). Supplier selection criteria and methods in supply chains: A review. International Journal of Social, Management, Economics and Business Engineering, 7(10), 1403-1409.

Priya, P., Iyakutti, K., \& Devi, S. P. (2012). E-procurement system with embedded supplier selection DSS for an automobile manufacturing industry. International Journal of Database Management systems, 4(2), 85.

Parasuraman, A., Zeithaml, V. A., \& Berry, L. L. (1988). Servqual: A multiple-item scale for measuring consumer perc. Journal of retailing, 64(1), 12.

Park, R. (1999). The global transformation of financial services. European Business Journal, 11, 7 16.

Petroni, A., \& Braglia, M. (2000).Vendor selection using principal component analysis. Journal of Supply Chain Management, 36(1), 63-69.

Phan, D., \& Stata, N. (2002). E-business success at Intel: an organization ecology and resource dependence perspective. Industrial Management \& Data Systems, 102(4), 211-217.

Pi, W. N., \& Low, C. (2005). Supplier evaluation and selection using Taguchi loss functions. The International Journal of Advanced Manufacturing Technology, 26(1-2), 155-160.

Prahinski, C., \& Benton, W. C. (2004). Supplier evaluations: communication strategies to improve supplier performance. Journal of Operations Management, 22(1), 39-62.

Pugliese, A. J., \& Halse, R. (2000). SysTrust and WebTrust: technology assurance opportunities. The CPA Journal, 70(11), 28.

Railsback, K. (2001). PKI is key to secure e-commerce. InfoWorld, 23(5), 64-64.

Rakesh Garg, R.K. Sharma, Kapil Sharma, R.K.Garg (n.d.). Optimal selection of commercial off-theshelf using Fuzzy Modified Distance Based Approach.

Ramanathan, R. (2007). Supplier selection problem: integrating DEA with the approaches of total cost of ownership and AHP. Supply Chain Management: An International Journal, 12(4), 258-261.

Ratnasingam, P., \& Pavlou, P. A. (2003).Technology trust in internet-based inter-organizational electronic commerce. Journal of Electronic Commerce in Organizations (JECO), 1(1), 17-41.

Reichheld, F. F., \& Schefter, P. (2000). E-loyalty: your secret weapon on the web. Harvard business review, 78(4), 105-113.

Rishi kumar, R.K. Garg (2013). Sensitivity Analysis on the Rankings of Robot Obtained from DBA method. International Journal of Engineering, Applied and Management Sciences Paradigms, 1(2).

Sanayei, A., Mousavi, S. F., \& Yazdankhah, A. (2010). Group decision making process for supplier selection with VIKOR under fuzzy environment. Expert Systems with Applications, 37(1), 24-30.

Schröder, M. J., \& McEachern, M. G. (2002). ISO 9001 as an audit frame for integrated quality management in meat supply chains: the example of Scottish beef. Managerial Auditing Journal, 17(1/2), 79-85.

Shakey, B. K. (2006). Supplier selection using AHP and promethee-2. Int J Sci Res, 6, 156-160.

Sharma, K., Garg, R., Nagpal, C. K., \& Garg, R. K. (2010). Selection of optimal software reliability growth models using a distance based approach. IEEE Transactions on Reliability, 59(2), 266-276. 
Shemshadi, A., Shirazi, H., Toreihi, M., \& Tarokh, M. J. (2011). A fuzzy VIKOR method for supplier selection based on entropy measure for objective weighting. Expert Systems with Applications, 38(10), 12160-12167.

Soliman, K. S., \& Janz, B. D. (2004). An exploratory study to identify the critical factors affecting the decision to establish Internet-based interorganizational information systems. Information \& Management, 41(6), 697-706.

Tracica, B. (2002). Diffusion of electronic commerce in developing countries: The case of Costa Rica. Journal of Global Information Technology Management, 5(1), 4-24.

Tsai, Y. L., Yang, Y. J., \& Lin, C. H. (2010). A dynamic decision approach for supplier selection using ant colony system. Expert Systems with Applications, 37(12), 8313-8321.

Turner, J. C., \& Davies, W. P. (2002, March). The modern food chain: profiting from effective integration. In Trade Partners UK and Ministry of Agriculture Modern Food Chain Seminar, Kuala Lumpur (Vol. 26, pp. 1-37).

Vaidyanathan, G., \& Devaraj, S. (2008). The role of quality in e-procurement performance: An empirical analysis. Journal of Operations Management, 26(3), 407-425.

Vinodh, S., Ramiya, R. A., \& Gautham, S. G. (2011). Application of fuzzy analytic network process for supplier selection in a manufacturing organisation. Expert Systems with Applications, 38(1), 272280.

Weber, C. A., Current, J. R., \& Benton, W. C. (1991). Vendor selection criteria and methods. European Journal of Operational Research, 50(1), 2-18.

Williams, T., Maull, R., \& Ellis, B. (2002). Demand chain management theory: constraints and development from global aerospace supply webs. Journal of Operations Management, 20(6), 691706.

Wixom, B. H., \& Watson, H. J. (2001). An empirical investigation of the factors affecting data warehousing success. MIS quarterly, 25(1), 17-41.

Wu, D. D. (2010). Supplier selection in a fuzzy group setting: A method using grey related analysis and Dempster-Shafer theory. Expert Systems with Applications, 36(5), 8892-8899.

Wu, W. Y., Sukoco, B. M., Li, C. Y., \& Chen, S. H. (2009). An integrated multi-objective decisionmaking process for supplier selection with bundling problem. Expert Systems with Applications, 36(2), 2327-2337.

Yang, C. C., \& Chen, B. S. (2006). Supplier selection using combined analytical hierarchy process and grey relational analysis. Journal of Manufacturing Technology Management, 17(7), 926-941.

Valahzaghard, M. K., Mozaffari, M. M., Valahzaghard, H. K., \& Memarzade, M. (2011). Supplier selection by using Fuzzy Delphi, Fuzzy AHP, and SIR VIKOR. American Journal of Science Research, 35, 24-45.

Young-Ybarra, C., \& Wiersema, M. (1999). Strategic flexibility in information technology alliances: The influence of transaction cost economics and social exchange theory. Organization science, 10(4), 439-459.

Zhang, D., Zhang, J., Lai, K. K., \& Lu, Y. (2009). An novel approach to supplier selection based on vague sets group decision. Expert Systems with Applications, 36(5), 9557-9563.

Zhu, K., \& Kraemer, K. L. (2002). E-commerce metrics for net-enhanced organizations: Assessing the value of e-commerce to firm performance in the manufacturing sector. Information Systems Research, 13(3), 275-295.

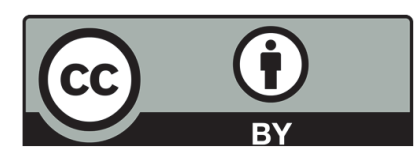

(C) 2019 by the authors; licensee Growing Science, Canada. This is an open access article distributed under the terms and conditions of the Creative Commons Attribution (CC-BY) license (http://creativecommons.org/licenses/by/4.0/). 